\title{
COMPUTER PREDICTION OF BIOLOGICAL ACTIVITY OF DIMETHYL-N-(BENZOYL)AMIDOPHOSPHATE AND DIMETHYL-N-(PHENYLSULFONYL)AMIDOPHOSPHATE, EVALUATION OF THEIR CYTOTOXIC ACTIVITY AGAINST LEUKEMIC CELLS IN VITRO
}

\author{
I. I. GRYNYUK, S. V. PRYLUTSKA, N. S. KARIAKA, T. Yu. SLIVA, \\ O. V. MOROZ, D. V. FRANSKEVYCH, V. M. AMIRKHANOV, \\ O. P. MATYSHEVSKA, M. S. SLOBODYANIK
}

Taras Shevchenko National University of Kyiv, Ukraine; e-mail: igrynyuk@yahoo.com

\begin{abstract}
Structural analogues of $\beta$-diketones - dimethyl-N-(benzoyl)amidophosphate (HCP) and dimethyl-N(phenylsulfonyl)amidophosphate (HSP) were synthesized and identified by the methods of $I R,{ }^{1} \mathrm{H}$ and ${ }^{31} \mathrm{P} N M R$ spectroscopy. Screening of biological activity and calculation of physicochemical parameters of HCP and HSP compounds were done with the use of PASS and ACD/Labs computer programs. A wide range of biological activity of synthesized compounds, antitumor activity in particular, has been found. Calculations of the bioavailability criteria indicate that the investigated compounds have no deviations from Lipinski's rules. HCP compound is characterized by a high lipophilicity at physiological pH as compared to HSP. It was found that cytotoxic effect of the studied compounds on the leukemic L1210 cells was of time-and dose-dependent character. HCP is characterized by more pronounced and early cytotoxic effects as compared to HSP. It was shown that $2.5 \mathrm{mM} H C P$ increased ROS production 3 times in the early period of incubation, and decreased cell viability by $40 \%$ after $48 \mathrm{~h}$, and by $66 \%$ - after $72 \mathrm{~h}$. Based on the computer calculation and undertaken research, HCP was selected for target chemical modifications and enhancement of its antitumor effect.
\end{abstract}

Key words: dimethyl-N-(benzoyl)amidophosphate, dimethyl-N-(phenylsulfonyl)amidophosphate, PASSprognosis, L1210 leukemic cells, ROS, cytotoxicity.

$\mathrm{O}$ ne of possible directions of an efficient search for the ways of practical use of synthesized chemical compounds today is the prediction of probable kinds of their biologic activity in silico based on the structural formula with the use of new computer analysis technologies. Chemical compounds, which display cytotoxic and anti-tumor action and possess chemotherapeutic potential, deserve special attention.

Structural analogues of $\beta$-diketones, specifically sulphonylamidophosphates (SAPh) - compounds with $\mathrm{S}\left(\mathrm{O}_{2}\right) \mathrm{N}(\mathrm{H}) \mathrm{P}(\mathrm{O})=$ fragment and carbacylamidophosphates (CAPh) - compounds with functional $\mathrm{C}(\mathrm{O}) \mathrm{N}(\mathrm{H}) \mathrm{P}(\mathrm{O})=$ fragment are attractive objects of research in this direction. Sulphonamide group $\left(-\mathrm{SO}_{2}-\mathrm{NH}^{-}\right)$is a structural fragment of a number of antiseptic drugs, as well as enzymes inhibitors used in chemotherapeutic practice [1]. Availability of phosphoryl group with high value of negative charge on the oxygen atom in the struc- ture of these compounds determines their affinity for metal ions, as well as a capacity of complex formation and coordination binding with biological molecules, that allows affecting their conformation and activity [2]. Variation of substituents near phosphoryl, sulphonyl and carboxyl groups in SAPh and CAPh composition creates additional conditions for purposeful search of new compounds, in particular those with antitumor action. One of the simplest representatives of CAPh and SAPh classes are dimethyl-N-(benzoyl)amidophosphate (HCP) and dimethyl-N-(phenylsulfonyl)amidophosphate (HSP). Abbreviations for the synthesized compounds - HCP and HSP reflect their acid character (symbol H), presence of phosphorus in their composition (symbol P), as well as the difference in composition of their chelating node OXNPO - in HCP compound X is the carbon atom, and in HSP compound $\mathrm{X}$ is the sulphur atom. A rather broad set of displaying biologic activity, antitumor action in 
particular, is available in the computer database for these compounds. However, a necessary stage of studying such action of the researched compounds is an experimental estimation of their effects with the use of transformed cell lines.

The work's aim was to calculate physicochemical parameters of synthesized compounds - dimethyl-N-(benzoyl)amidephosphate and dimethyl$\mathrm{N}$-(phenylsulfonyl)amidephosphate, to perform computer prediction of their antitumor activity with the use of PASS (Prediction of Activity Spectra for Substances) and ACD/Labs computer programs and to estimate toxic effect of these compounds on L1210 leukemic cells.

\section{Materials and Methods}

Synthesis and structure of HCP and HSP compounds. Initial compounds: benzamide (99\%, Sigma-Aldrich), benzolsulphonamide (99\%, Sigma-Aldrich), phosphorus pentachloride (reagent grade, 95\%, Sigma-Aldrich), concentrated sulfuric acid $(\geq 95 \%$, Trace SELECT Ultra, for ultratrace analysis, Sigma-Aldrich), methyl alcohol (99.8\%, LABSCAN), as well as solvents $\left(\mathrm{CCl}_{4}\right.$, dioxane and 2-propanol), chempure purity grade (SINBIAS). Synthesis of dimethyl-N-(benzoyl)amidephosphate and dimethyl-N-(phenylsulfonyl)amidephosphate was carried out by the methods of $[3,4]$.

IR spectra of compounds were registered in the range of $4000-400 \mathrm{~cm}^{-1}$ by Fourier spectrometer FT-IR Spectrum BX-II Perkin Elmer (samples in a form of tablets with $\mathrm{KBr}$ ). Spectra ${ }^{1} \mathrm{H}$ NMR (TMC standard) were registered at room temperature by pulse radiospectrometer Varian Mercury 400 with operation frequency $400 \mathrm{MHz}$. The compound dilutions in DMSO-d6 were used for recording spectra. Registration of spectra ${ }^{31} \mathrm{P} \mathrm{NMR}\left(\mathrm{H}_{3} \mathrm{PO}_{4}\right.$ outer standard) was performed by spectrometer AVANCE 400 of Bruker company.

The obtained compounds were diluted to the final concentration of $0.05 \mathrm{M}$.

Physicochemical parameters of HCP and HSP compounds were estimated using ACD/Labs and PASS computer programs.

Screening of probable biologic activity of compounds was performed using PASS computer program [5].

Cultivation of cells. Cells of mouse lymphocytic leukemic line L1210 were obtained from the bank of cell lines at R. E. Kavetsky Institute of Experimental Pathology, Oncology and Radiology of NAS of Ukraine. The cells were grown in RPMI 1640 medium in the presence of $10 \%$ fetal calf serum, $2 \mathrm{mM}$ of L-glutamine, $50 \mathrm{IU} / \mathrm{ml}$ of penicillin, $50 \mu \mathrm{g} / \mathrm{ml}$ of streptomycin in a moistened atmosphere containing $5 \%$ of $\mathrm{CO}_{2}$ at $37^{\circ} \mathrm{C}$. L1210 cells were passaged in the ratio 1:3-1:5 every 2-3 days when they reached the concentration of $10^{6}$ cells $/ \mathrm{ml}$.

Cells $\left(0.2 \cdot 10^{6}\right.$ cells $\left./ \mathrm{ml}\right)$ were incubated during different time intervals (24, 48 and $72 \mathrm{~h}$ ) in the absence (control) and in the presence of the studied chemical compounds.

Viability of cells was evaluated by the reduction rate of 3-[4, 5-dimethylthiasole-2-yl]-2,5-diphenyl tetrazolium bromide (MTT) [6]. The reaction was conducted in 96-well plates. The number of cells in the well was $4 \cdot 10^{5}$ in the volume of $200 \mu 1$. MTT solution $(4 \mathrm{mg} / \mathrm{ml})$ was added to each well in amount of $20 \mu \mathrm{l}$ and incubated during $2 \mathrm{~h}$ at $37^{\circ} \mathrm{C}$. After incubation the plates were centrifuged ( $600 \mathrm{~g}, 7 \mathrm{~min}$ ) and kept in darkness at a temperature of $4{ }^{\circ} \mathrm{C}$ for $20 \mathrm{~h}$. Formazan sediment was diluted in $150 \mu \mathrm{l}$ of concentrated solution of dimethylsulphoxide. Fifteen minutes later the extinction was measured by a digital spectrophotometer ( $\mu$ Quant, BioTEK, USA) under $\lambda=570 \mathrm{~nm}$. Viability of cells was expressed as a percentage of control.

The number of viable cells was determined after their staining with trypan blue (final concentration $0.4 \%$ ) by calculating in the Goryaev chamber. Morphological state of cells was evaluated by means of the light microscope Olympus CKX41SF (Japan).

Production of reactive oxygen species (ROS) in cells was determined with the use of 2,7-dichlorhydrofluorescein diacetate (Sigma, USA), which was added directly to the cell incubation medium $\left(2 \cdot 10^{6} /\right.$ $\mathrm{ml})$ to the end concentration of $5 \mu \mathrm{mol} / \mathrm{l}$ in a sample. The probe fluorescence intensity was estimated by spectrofluorimeter Shimadzu 150 RF (Japan), excitation wavelength $\left(\lambda_{\text {exc }}\right)-480 \mathrm{~nm}$, emission wavelength $\left(\lambda_{\text {em }}\right)-520 \mathrm{~nm}[7]$.

\section{Results and Discussion}

Dozens of compounds of CAPh and SAPh classes have been synthesized and investigated by physicochemical methods of analysis by this time [8-10]. It was shown that the compounds of CAPh class can be coordinated to metal in bidentate chelating manner (through oxygen atoms of carbonyl and phosphoryl groups) in the deprotonated form and in monodentate way (through oxygen atom of phosphoryl group) - in the neutral form. The num- 
ber of already known SAPh compounds and complexes on their basis is considerably less than that of carbacylamidophosphates [8]. Only bidentate and bidentate-bridge ways of coordination are known for SAPh compounds.

The composition of HCP and HSP compounds is confirmed by NMR and IR spectroscopy, by measuring melting points.

HCP: Melt. point $119^{\circ} \mathrm{C}$; IR (KBr): $v_{\max }=3144$, 1683 (CO), 1600, 1579, 1458, 1431, 1278, 1242 (PO), 1188, 1043, 903, 860, 775, 715, 517, $470 \mathrm{~cm}^{-1}$; ${ }^{1} \mathrm{HNMR}$ (DMSO-d6) -: $\delta=9.87(\mathrm{~d}, 1 \mathrm{H}, \mathrm{NH}), 7.97$ (d, 2H, Ph), 7.56 (t, 1H, Ph), 7.45 (t, 2H, Ph), 3.78 (d, $\left.6 \mathrm{H}, \mathrm{OCH}_{3}\right) ;{ }^{31} \mathrm{PNMR}\left(\mathrm{CH}_{3} \mathrm{CN}\right): \mathrm{d}=1.22(\mathrm{~s})$.

HSP: Melt. point $121^{\circ} \mathrm{C}$; IR (KBr): $v_{\max }=3000$, 2745, 1455, 1410, 1320 (vas(SO)), 1260 (PO), 1185( $\left.v_{\mathrm{s}}(\mathrm{SO})\right), 1100,1075,1060,955,885,855,780$, 695, 605, 585, 535, 495, $435 \mathrm{~cm}^{-1}$. ${ }^{1} \mathrm{HNMR}$ (DMSOd6): $\delta=7.91(\mathrm{~m}, 2 \mathrm{H}, \mathrm{Ph}), 7.65(\mathrm{~m}, 1 \mathrm{H}, \mathrm{Ph}), 7.58(\mathrm{~m}$, 2H, Ph), 3.57 (d, 6H, OCH3); ${ }^{31}$ PNMR (DMSO): $\mathrm{d}=-2.17(\mathrm{~s})$.

The results obtained evidence that the degree of purity of HCP and HSP compounds is $\geq 98 \%$.

HCP and HSP compounds differ only in the composition of their chelating node OXNPO: $\mathrm{X}$ is the carbon atom in HCP (Fig. 1, $A$ ), and the sulfur atom in HSP compound (Fig. 1, $B$ ).

PASS computer program was used to predict biological activity of the compounds under study. It permits us to predict above 4000 kinds of biological activity, as well as the mechanism of action, mutagenicity, carcinogenicity, interaction with target molecules, etc., following the structural formula of a chemical substance. The average prediction accuracy is $95 \%$, and probability of occasional guessing of one of 4000 kinds of activity - about $0.1 \%$ [5]. The prediction results obtained with the help of PASS computer program are presented as a list of probable kinds of activity with calculated evaluation of availability (Pa) or absence of each kind of activity (Pi), in a range of values from 0 to 1 .

According to results obtained with the use of PASS program the studied compounds can display a broad range of biological activity (Table 1). HCP and HSP compounds have much in common in the predicted activity: the inhibition of antioxidant enzymes activity, ability to affect the oxygen content, activation of caspase-8, antitumor and antileukemia activity. But there are also some differences: HCP can be an apoptosis inducer, a caspase-3 activator and an alkylator, while HSP can display an analge-

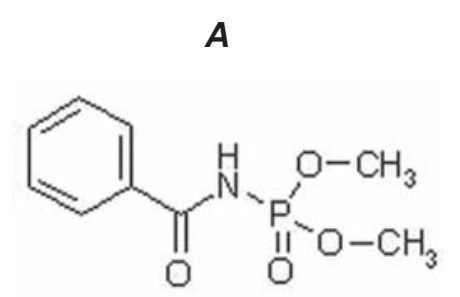

B

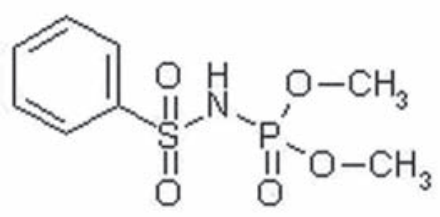

Fig. 1. Structural formulas of $\mathrm{HCP}(A)$ and $\operatorname{HSP}(B)$ compounds

sic effect, affect the level of calcium ions in a cell, regulate proliferation through activation of MAP kinase. A common predicted property of the studied compounds is their antitumor effect. L1210 mouse lymphocytic leukemic cells were chosen as a biologic object for its evaluation.

Using PASS program we can predict a kind of biological activity of a chemical compound, but efficient concentrations and term of the action are to be determined in the experimental researches in vitro.

The influence of chemical compounds in concentration range of $0.01-2.5 \mathrm{mM}$ on viability of L1210 cells was investigated in the dynamics of incubation at 24, 48 and $72 \mathrm{~h}$, taking the content of viable cells without additions as $100 \%$ (control). The investigated compounds in concentration of $0.01 \mathrm{mM}$ did not affect the viability of L1210 cells at $72 \mathrm{~h}$ of incubation (data are not presented).

The toxic effect of HCP compound in concentrations 1.25 and $2.5 \mathrm{mM}$ on leukemic cells (Fig. 2, $A$ ) was detected. The dynamics of display of cytotoxic effect of the studied compounds was delayed. Thus, under the effect of HCP in concentration of $1.25 \mathrm{mM}$, a $30 \%$ decrease of the cells viability was observed in 48 and a 50\% decrease - in $72 \mathrm{~h}$.

With HCP concentration being increased to $2.5 \mathrm{mM}$, the cell viability decreased by $40 \%$ in $48 \mathrm{~h}$, in $72 \mathrm{~h}$ the cytotoxic effect was enhanced and the cell viability decreased by 66\% (Fig. 2, A). The toxic effect of HSP compound on L1210 leukemic cells was less expressed. At a concentration of $2.5 \mathrm{mM}$ the decrease of L1210 cells viability by $30 \%$ was observed within $48 \mathrm{~h}$, however no further increase of 
Ta ble 1. Predicted kinds of HCP and HSP biological activity according to PASS computer program

\begin{tabular}{|c|c|c|c|c|}
\hline № & Chemical compound & $\mathrm{Pa}$ & $\mathrm{Pi}$ & Type of biological activity \\
\hline \multirow[t]{11}{*}{1} & HCP & 0.710 & 0.004 & Antineoplastic enhancer \\
\hline & Molecular Formula: $\mathrm{C}_{9} \mathrm{H}_{12} \mathrm{NO}_{4} \mathrm{P}$ & 0.626 & 0.010 & $\begin{array}{l}\text { Antineoplastic (non- } \\
\text { Hodgkin’s lymphoma) }\end{array}$ \\
\hline & ChemSpider ID: 1284096 & 0.472 & 0.024 & Caspase 8 activator \\
\hline & & 0.445 & 0.072 & Oxygen scavenger \\
\hline & Systematic name & 0.395 & 0.075 & Apoptosis agonist \\
\hline & Dimethyl-N-(benzoyl)amidophosphate & 0.364 & 0.067 & Caspase 3 activator \\
\hline & & 0.259 & 0.024 & $\begin{array}{l}\text { Antineoplastic (lymphocytic } \\
\text { leukemia) }\end{array}$ \\
\hline & & 0.208 & 0.059 & Glutathione peroxidase inhibitor \\
\hline & & 0.241 & 0.098 & Antitoxic \\
\hline & & 0.132 & 0.052 & Glutathione synthase inhibitor \\
\hline & & 0.117 & 0.059 & Antineoplastic, alkylator \\
\hline \multirow[t]{9}{*}{2} & HSP & 0.995 & 0.003 & Analgesic, non-opioid \\
\hline & Molecular Formula: $\mathrm{C}_{8} \mathrm{H}_{12} \mathrm{NO}_{5} \mathrm{PS}$ & 0.360 & 0.013 & Antineoplastic enhancer \\
\hline & $8^{2}-12=$ & 0.375 & 0.112 & MAP kinase stimulant \\
\hline & ChemSpider ID: 1721921 & 0.301 & 0.141 & Caspase 8 activator \\
\hline & & 0.276 & 0.141 & Superoxide dismutase inhibitor \\
\hline & Systematic name & 0.279 & 0.145 & Calcium regulator \\
\hline & Dimethyl-N-(phenylsulfonyl)amidophosphate & 0.306 & 0.172 & Oxygen scavenger \\
\hline & & 0.189 & 0.070 & Glutathione peroxidase inhibitor \\
\hline & & 0.118 & 0.080 & $\begin{array}{l}\text { Antineoplastic (lymphocytic } \\
\text { leukemia) }\end{array}$ \\
\hline
\end{tabular}

$\mathrm{Pa}$ - probability of revealing activity; $\mathrm{Pi}$ - probability of the absence of activity.
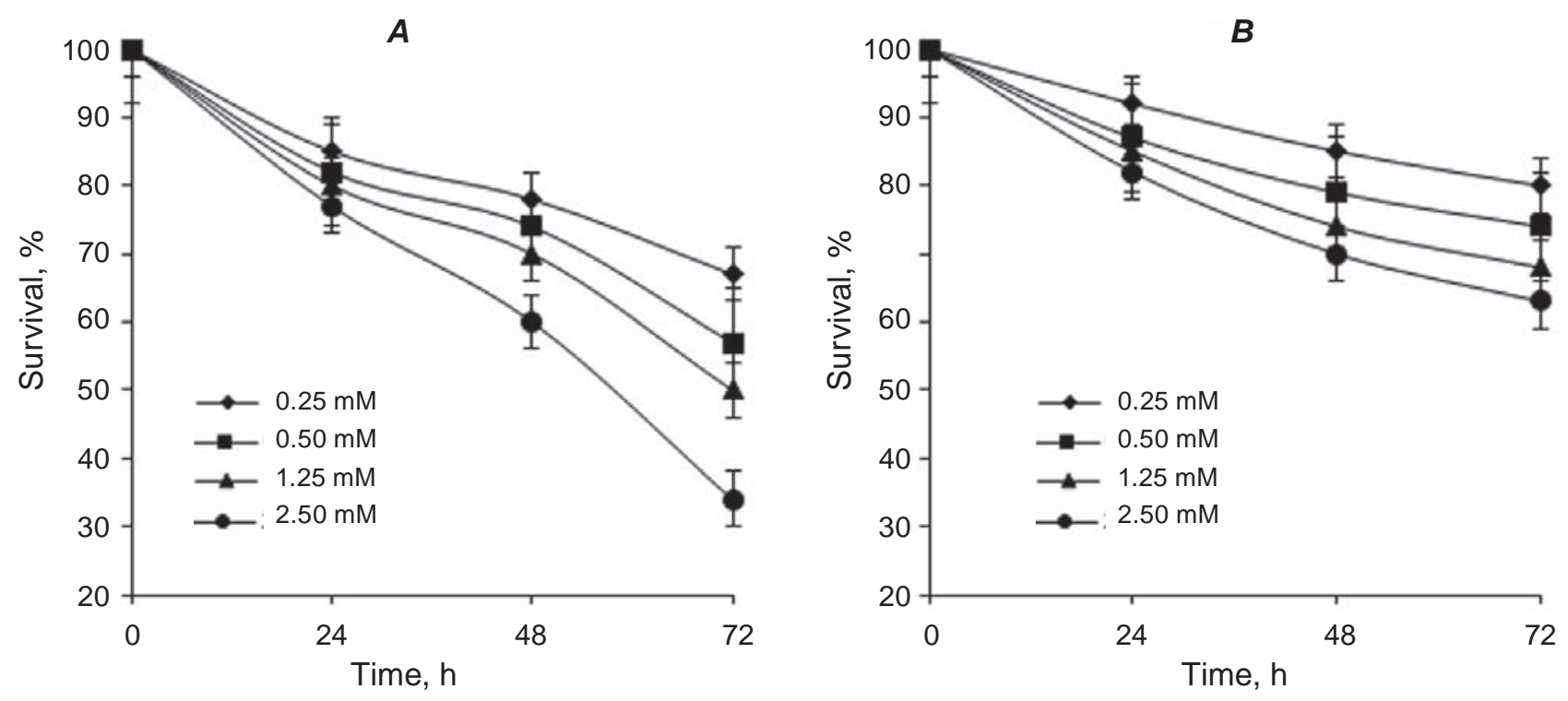

Fig. 2. Viability of L1210 cells in dynamics of incubation with HCP (A) and HSP (B) in different concentrations 


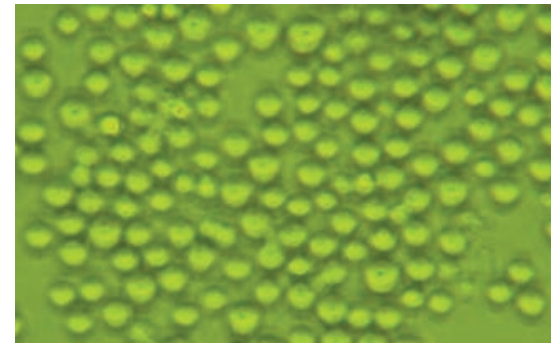

L1210 control

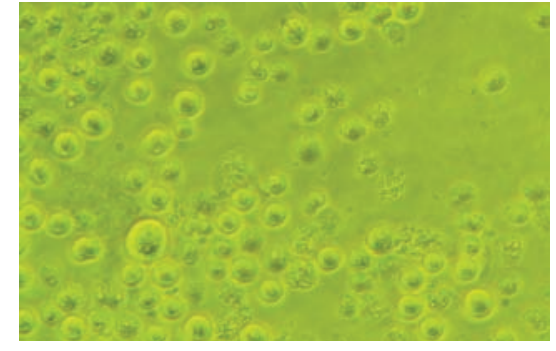

$\mathrm{L} 1210+2,5 \mathrm{mM}$ HCP

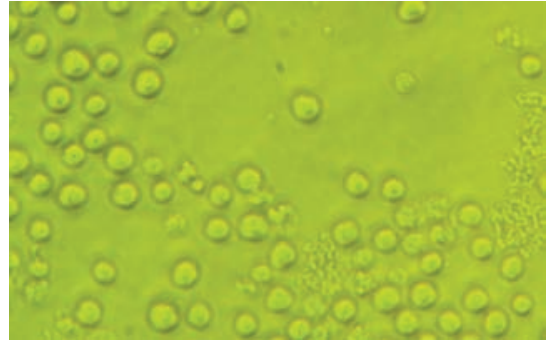

L1210 +2,5 mM HSP

Fig. 3. Microphotographs of L1210 cells incubated for 48 h with HCP or HSP (phasecontrast microscope, $\times 400)$

cytotoxic effect was observed within the following terms (Fig. 2, B).

Morphologic analysis showed that L1210 cells treated for $48 \mathrm{~h}$ with $2.5 \mathrm{mM}$ HCP or HSP differed from those in control. Fragmented cells, as well as the enlarged cells, with swollen nuclei appeared in the field of vision (Fig. 3). The number of viable L1210 cells was found to be decreased by $33 \%$ at $48 \mathrm{~h}$ and by $50 \%$ - at $72 \mathrm{~h}$ of incubation (Table 2). Treatment with $2.5 \mathrm{mM}$ HSP resulted in a decrease of the number of cells without substantial changes of their morphologic features (Fig. 3, Table 2).

Thus, as a result of both virtual screening and experimental research, HCP compound proved to be more cytotoxic to the tumor cells compared to HSP compound.

ROS production in the intracellular space and development of oxidative stress is supposed to be one of possible mechanisms of a toxic effect of chemical compounds. ROS production in L1210 cells was evaluated 2 and $5 \mathrm{~h}$ after adding HCP and HSP compounds in concentration of $2.5 \mathrm{mM}$. No significant changes in ROS level in the cells were revealed two hours after HCP and HSP introduction into incubation medium. But with the incubation term being increased to $5 \mathrm{~h}$, a decrease of ROS level in L1210 cells was observed. ROS production was more intensive under the effect of HCP (a 3-fold intensification compared to control), than under the effect of HSP (a 2-fold intensification) (Fig. 4). A higher prooxidant activity of HCP compound is assumed to determine its higher cytotoxic effect on the cells.

Both the structure and physicochemical properties of chemical compounds are of importance for explaining possible mechanisms of their biological activity. One of the criteria for recommendation of the chemical compounds as pharmacologic preparations is their correspondence to the so-called Lipin-
Table 2. The number of viable L1210 cells (\% of control) at different time after incubation with chemical compounds $(M \pm m, n=4)$

\begin{tabular}{lc|cc}
\hline \multirow{2}{*}{ Chemical compound } & \multicolumn{2}{|c}{ Time, $\mathrm{h}$} \\
\cline { 3 - 4 } & & 48 & 72 \\
\hline HCP & $1.25 \mathrm{mM}$ & $73 \pm 2^{*}$ & $65 \pm 5^{*}$ \\
& $2.5 \mathrm{mM}$ & $67 \pm 3^{*}$ & $50 \pm 4^{*}$ \\
$\mathrm{HSP}$ & $1.25 \mathrm{mM}$ & $80 \pm 5$ & $80 \pm 5$ \\
& $2.5 \mathrm{mM}$ & $75 \pm 6^{*}$ & $70 \pm 6^{*}$ \\
\hline
\end{tabular}

$* P \leq 0.05$ compared to a sample incubated without additions.

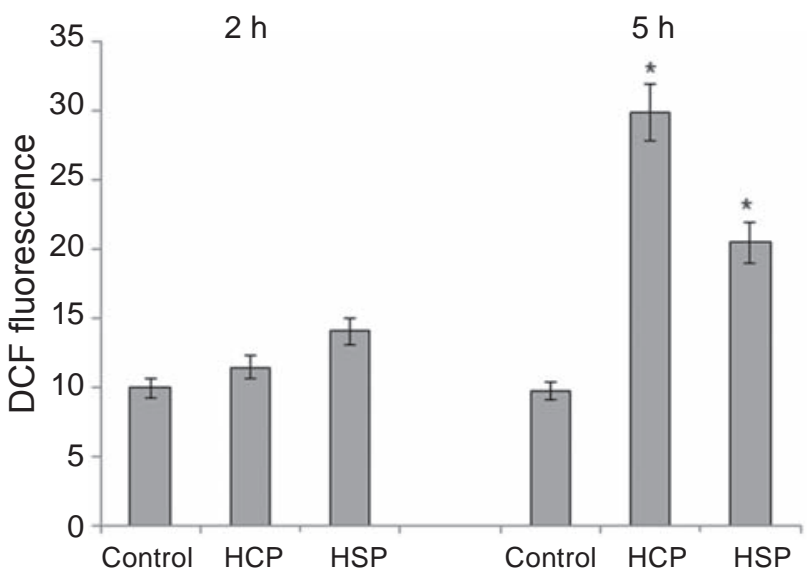

Fig. 4. ROS level in L1210 cells after adding $2.5 \mathrm{mM}$ $H C P$ and HSP into incubation medium of $(M \pm m$, $n=6)$

ski's rules, according to which a compound being a candidate to medicine should meet the following requirements: molecular mass $\left(\mathrm{M}_{\mathrm{m}}\right)$ no more than $500 \mathrm{Da}$; lipophilicity parameter, or coefficient of distribution in an octanol/water system $(\log \mathrm{P})$ - no more than 5; the number of hydrogen bond donors - 
no more than 5; the number of hydrogen bond acceptors - no more than 10 . If two or more requirements of these rules are not satisafied, there is a risk of the low compound bioavailability [11].

Besides Lipinski's rules the indexes of molecular polar surface area $\left(\leq 140 \AA^{2}\right)$, the number of rotating nonterminal bonds (no more than 10 ), the number of aromatic rings (no more than 4) are recommended for evaluation of bioavailability of chemical compounds [12-14]. Physicochemical parameters of HCP and HSP calculated with the use of ACD/ Labs program are presented in Table 3.

The analysis of results obtained shows that HCP and HSP compounds meet the requirements of both Lipinsky's and Weber's rules.

One of the basic criteria of biological activity of a chemical compound is its lipophilicity estimated by the coefficient of distribution in an octanol/water system $(\log P)$. The choice of n-octanol as a comparison phase is based on the fact that the balance of polar and nonpolar fragments in the molecule of n-octanol imitates adequately the lipophilic properties of lipids and proteins in the cells and tissues of animals and plants. The penetration of compound through cell membranes, binding to biomacromolecules, adsorption, distribution, metabolism, removal and toxicity $[14,15]$ depend on the degree of the compound lipophilicity. According to theoretical calculations (Table 3), $\log \mathrm{P}$ parameter was 0.33 and 0.11 for HCP and HSP, respectively, that evidences for a higher lipophilicity of HCP.

Lipophilicity of HCP and HSP as representatives of weak $\mathrm{NH}$-acids, is more precisely estimated by $\log \mathrm{D}$ parameter, which represents the ratio of general concentration of a compound (its ionized and nonionized form) in two liquid phases (octanol/ water) and is dependent on the medium $\mathrm{pH}$.

The dependence of $\log \mathrm{D}$ index for HCP and HSP compounds on the medium $\mathrm{pH}$ is shown on Fig 5. It is established that HCP compound is better
Table 3. Physicochemical parameters of HCP and HSP compounds calculated with the use of ACD/Labs program

\begin{tabular}{l|cc}
\hline \multicolumn{1}{c}{\begin{tabular}{c} 
Physicochemical \\
\multicolumn{1}{c}{ parameters }
\end{tabular}} & \multicolumn{2}{c}{ Chemical compounds } \\
\cline { 2 - 3 } & HCP & HSP \\
\hline $\mathrm{M}_{\mathrm{m}}$, Da & 229.17 & 265.22 \\
$\log \mathrm{P}$ & 0.33 & 0.11 \\
$\mathrm{H}$ bond donors & 1 & 1 \\
H bond acceptors & 5 & 6 \\
Freely rotating bonds & 4 & 5 \\
Polar surface area, $\AA^{2}$ & 74 & 100 \\
pKa & 9.66 & 2.37 \\
\hline
\end{tabular}

dissolved in octanol than in water when $\mathrm{pH}$ values are below 10 (Fig. 5, $A$ ), while for HSP compound (Fig, $5, B$ ) this range is much more narrow (pH below 2) and does not correspond to physiological values (pH 7.4). It is known that high biological activity is, as a rule, a characteristic of the substances with intermediate solubility. Thus, $\log P$ value in the range of $-1-+5$ is optimal for substances intended for peroral use. If $\log \mathrm{P}>5$ the compound possesses high lipophilicity and its accumulation in lipid layer of membranes could prevent its absorption [14].

Thus, a more evident cytotoxic effect of HCP compound compared to HSP compound revealed by this study may be explained by its higher lipophilicity at physiological values of medium $\mathrm{pH}$ (7.4) and hence by better permeability through cell membranes and higher biological efficiency.

The higher value of negative logarithm of dissociation constant of HCP ( $\mathrm{pKa}=9.66)$ as compared to HSP $(\mathrm{pKa}=2.37)$ is also in agreement with its more evident toxic effect on L1210 cells. The probability of proton dissociation from HCP molecule is low, and hence the concentration of its nondissocia-
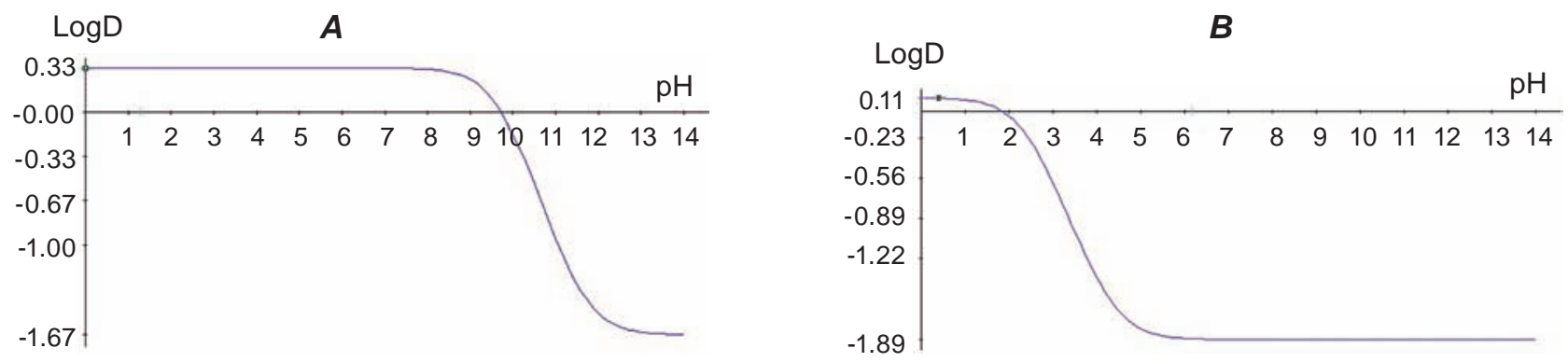

Fig. 5. Characterization of HCP (A) and HSP (B) lipophilicity by $\log D$ index 
ted (molecular) form is higher. This molecular form contains both electrophilic and nucleophilic centers, which are sterically distributed in such way that can interact with corresponding electro- and nucleophilic sections of proteins, nucleic acids and other biomolecules.

Based on computations and conducted research, one can conclude that HCP compound is promising for the purposeful chemical modification with the aim to intensify its antitumor effect. Thus, the introduction of substituents with already known anti-tumor activity (e.g., aziridine or dichlorodiethylamine group, etc.) near OCNHPO functional group could be useful. An alternative possible way of modification is the creation of complexes with nanostructures (in particular with fullerene $\mathrm{C}_{60}$ ) as drug carriers.

\section{КОМП'ЮТЕРНЕ ПРОГНОЗУВАННЯ БІОЛОГІЧНОЇ АКТИВНОСТІ ДИМЕТИЛ-N-(БЕНЗОЇЛ)- АМІДОФОСФАТУ І ДИМЕТИЛ- N-(ФЕНІЛСУЛЬФОНІЛ)- АМІДОФОСФАТУ, ОЦІНКА ЇХ ЦИТОТОКСИЧНОЇ ДІЇ НА ЛЕЙКОЗНІ КЛІТИНИ IN VITRO}

\section{I. Гринюк, С. В. Прилучька, Н. С. Каряка, Т. Ю. Слива, О. В. Мороз, Д. В. Франскевич, В. М. Амірханов, О. П. Матишевська, М. С. Слободяник}

Київський національний університет імені Тараса Шевченка, Київ; e-mail: igrynyuk@yahoo.com

Синтезовано та ідентифіковано методами ІЧ, ${ }^{1} \mathrm{H}$ та ${ }^{31} \mathrm{P}$ ЯМР спектроскопії структурні аналоги $\beta$-дикетонів - диметил$\mathrm{N}$-(бензоїл)амідофосфат (НСР) та диметил-N(фенілсульфоніл)амідофосфат (HSP). Iз використанням комп'ютерних програм PASS та ACD/ Labs здійснено скринінг біологічної активності та розраховані фізико-хімічні параметри сполук HCP та HSP. Виявлено широкий спектр біологічної активності цих сполук, зокрема протипухлинну активність. Теоретичні розрахунки критеріїв біодоступності вказують на те, що досліджувані сполуки не мають жодних відхилень від правил Ліпінського. Сполука НСР характеризується вищою ліпофільністю за фізіологічних значень $\mathrm{pH}$ порівняно з HSP. Продемонстровано часо- та дозозалежний цитоток- сичний ефект досліджуваних сполук щодо лейкозних клітин L1210. Виявлено більш виразний та ранній цитотоксичний ефект НСР порівняно з HSP. За дії сполуки НСР у концентрації 2,5 мМ спостерігалось 3-разове посилення продукування АФК у ранній період інкубації, зниження життєздатності клітин на $40 \%$ через 48 год і на 66\% - через 72 год. На підставі комп'ютерних розрахунків та проведених досліджень можна дійти висновку, що сполука НСР є перспективною для цілеспрямованої хімічної модифікації 3 метою посилення її протипухлинної дії.

К л ю ч о в (бензоїл)амідофосфат, диметил-N-(фенілсульфоніл)амідофосфат, PASS-прогноз, лейкозні клітини L1210, АФК, цитотоксичність.

\section{КОМПЬЮТЕРНОЕ ПРОГНОЗИРОВАНИЕ БИОЛОГИЧЕСКОЙ АКТИВНОСТИ ДИМЕТИЛ-N-(БЕНЗОИЛ)- АМИДОФОСФАТА И ДИМЕТИЛ- N-(ФЕНИЛСУЛЬФОНИЛ)- АМИДОФОСФАТА, ОЦЕНКА ИХ ЦИТОТОКСИЧЕСКОГО ДЕЙСТВИЯ НА ЛЕЙКОЗНЫЕ КЛЕТКИ IN VITRO}

\author{
И. И. Гринюк, С. В. Прилуиякая, \\ Н. С. Каряка, Т. Ю. Слива, О. В. Мороз, \\ Д. В. Франскевич, В. М. Амирханов, \\ О. П. Матышевская, Н. С. Слободяник
}
Киевский национальный университет имени Тараса Шевченко, Киев; e-mail: igrynyuk@yahoo.com

Синтезированы и идентифицированы методами ИК, ${ }^{1} \mathrm{H}$ и ${ }^{31} \mathrm{P}$ ЯМР спектроскопии структурные аналоги $\beta$-дикетонов диметил$\mathrm{N}$-(бензоил)амидофосфат (НСР) и диметил-N(фенилсульфонил)амидофосфат (HSP). C использованием компьютерных программ PASS и $\mathrm{ACD} / \mathrm{Labs}$ осуществлен скрининг биологической активности и рассчитаны физико-химические параметры соединений HCP и HSP. Выявлен широкий спектр биологической активности исследуемых соединений, в частности противоопухолевая активность. Теоретические расчеты критериев биодоступности указывают на то, что исследуемые соединения не имеют отклонений от правил Липинского. Соединение НСР харак- 
теризуется высокой липофильностью при физиологических значениях рН по сравнению с HSP. Продемонстрированы время- и дозозависимые цитотоксические эффекты исследуемых соединений в отношении лейкозных клеток L1210. Выявлен более выразительный и ранний цитотоксический эффект НСР по сравнению с HSP. При добавлении НСР в концентрации 2,5 мМ наблюдалось 3-кратное усиление выработки АФК в ранний период инкубации, снижение жизнеспособности клеток на $40 \%$ через 48 и на $66 \%$ - через 72 ч. На основании компьютерных расчетов и проведенных исследований сделан вывод, что соединение НСР является перспективным для целенаправленной химической модификации, усиливающей его противоопухолевое действие.

К л ю ч е в ы е с л о в а:диметил-N-(бензоил) амидофосфат, диметил-N-(фенилсульфонил) амидофосфат, PASS-прогноз, лейкозные клетки L1210, АФК, цитотоксичность.

\section{References}

1. Anand N. Sulfonamides and sulfones: M. E. Wolff (Ed.) Burger's Medicinal Chemistry and Drug Discovery. Therapeutic Agents.Wiley, New York, NY, 1996; 2: 527-544.

2. Slawin A. M. Z., Wainwright M., Woollins D. Phosphino-urea chemistry: preparation and structure of chelate and $\mathrm{P}-\mathrm{N}$ bond cleavage complexes. New J. Chem. 2000; 24(2): 69-71.

3. Kirsanov A. V. The mechanism of the reaction of phosphorus pentachloride with a carboxylic acid amide. Izv. Akad. Nauk SSSR Ser. Khim. 1954; 4: 646-655. (In Russian).

4. Kirsanov A. V., Makitra R. G. The reaction of phosphorus pentachloride with a carboxylic acid amide. Trichlorphosphazoatsils. Zhurn. Obshch. Khim. 1955; 36: 2134-2137. (In Russian).

5. Lagunin A., Filimonov D., Poroikov V. Multitargeted natural products evaluation based on biological activity prediction with PASS. Curr. Pharm. Des. 2010; 16(15): 1703-1717.

6. Carmichael J., Degraff W. G., Gazdar A. F., Minna J. D., Mitchell J. B. Evaluation of a tetrazolium-based semiautomated colorimetric assay: assessment of chemosensitivity testing. Cancer Res. 1987; 47(4): 936-942.
7. LeBel C. P., Ischiropoulos H., Bondy S. C. Evaluation of the probe 2',7'-dichlorofluorescin as an indicator of reactive oxygen species formation and oxidative stress. Chem. Res. Toxicol. 1992; 5(2): 227-231.

8. Gawryszewska P., Smolenski P. Ligands synthesis, characterization and role in biotechnology. Nova Science Publishers. New York. 2014; 295 p.

9. Trush V. A., Gubina K. E., Amirkhanov V. M., Swiatek-Kozlowska J., Domasevitch K. V. Spectroscopic and crystal structure data of the alkali-, thallium (I) and onic- salts of dimethylN-trichloracetylamidophosphate. Polyhedron. 2005; 24(9): 1007-1014.

10. Litsis O. O., Ovchynnikov V. A., Shishkina S. V., Sliva T. Yu., Amirkhanov V. M. Dinuclear3D metalcomplexesbasedona carbacylamidophosphate ligand: redetermination of the ligand crystal structure. Transit. Met. Chem. 2013; 38(4): 473479.

11. Lipinski C. A., Lombardo F., Dominy B. W., Feeney P. J. Experimental and computational approaches to estimate solubility and permeability in drug discovery and development settings. Adv. Drug. Deliv. Rev. 1997; 23(1-3): 3-25.

12. Veber D. F., Johnson S. R., Cheng H.-Y., Smith B. R., Ward K. W., Kopple K. D. Molecular properties that influence the oral bioavailability of drug candidates. J. Med. Chem. 2002; 45(12): 2615-2623.

13. Kasim N. A., Whitehouse M., Ramachandran C., Bermejo M., Lennernäs H., Hussain A. S., Junginger H. E., Stavchansky S. A., Midha K. K., Shah V. P., Amidon G. L. Molecular properties of WHO essential drugs and provisional biopharmaceutical classification. Mol. Pharm. 2004; 1(1): 85-96.

14. Kerns E. H., Di L. Drug-like Properties: Concepts, Structure Design and Methods from ADME to Toxicity Optimization. Elsevier Inc, 2008; $528 \mathrm{p}$.

15. Liu X., Testa B., Fahr A. Lipophilicity and its relationship with passive drug permeation. Pharm. Res. 2011; 28(5): 962-977.

Received 10.07.2015 